\title{
'Where there is a will, there is a way': Belief in school meritocracy and the social-class achievement gap
}

\author{
Céline Darnon'*, Virginie Wiederkehr', Benoît Dompnier ${ }^{2}$ and \\ Delphine Martinot' \\ 'Clermont Auvergne University, CNRS, LAPSCO, Clermont-Ferrand, France \\ ${ }^{2}$ University of Lausanne, Switzerland
}

\begin{abstract}
Meritocratic ideology can promote system justification and the perpetuation of inequalities. The present research tests whether priming merit in the school context enhances the effect of socioeconomic status (SES) on school achievement. French fifth graders read a text priming either school merit or a neutral content, reported their French and mathematics self-efficacy as well as their belief in school meritocracy (BSM), and then took French and mathematics tests. Compared to the neutral condition, the merit prime condition increased the SES achievement gap. Self-efficacy and BSM were tested as two potential mediators of the effect. The results support a mediated moderation model in which belief in school meritocracy is the mechanism through which the merit prime increased the SES achievement gap.
\end{abstract}

Who has never told a child that 'where there is a will, there is a way' and that working hard is the pathway to success, particularly, at school? There are few doubts that effort and hard work should be valued at school. However, the purpose of the present paper is to highlight a possible dark side effect of promoting meritocracy in the context of school. Indeed, in that context, the promotion of school meritocracy may contribute to the reproduction of social inequalities.

\section{School and meritocracy}

Believing in descriptive meritocracy means believing that ability and hard work are the main determinants of success (Son Hing et al., 2011). At school, it refers to the conviction that ability and hard work lead to school success and, conversely, that the lack of success may be due to a lack of effort or school abilities (Jost \& Hunyady, 2002; Wiederkehr, Bonnot, Krauth-Gruber, \& Darnon, 2015). School meritocracy is often presented as a way to fight social inequalities because, in meritocratic beliefs, success is perceived as the direct consequence of children's deservingness and not of irrelevant factors such as social class, gender, or ethnicity. However, the pattern of stratification among groups in the school system shows that the goal of meritocracy is not being met

*Correspondence should be addressed to Céline Darnon, Université Clermont Auvergne, CNRS, LAPSCO, F-63000 Clermont-Ferrand, France (email: celine.darnon@uca.fr). 
(Mijs, 2016) because school success is influenced by factors unrelated to real merit. Social class is one such factor (Bradley \& Corwyn, 2002; Goudeau, Autin, \& Croizet, 2017; Sirin, 2005; White, 1982). An SES achievement gap exists before entering school and expands as children progress through school, most notably in mathematics skills (Galindo \& Sonnenschein, 2015; Jordan \& Levine, 2009) and reading and language skills (Aikens \& Barbarin, 2008; Arnold \& Doctoroff, 2003). Indeed, by promoting norms, values, practices, and language that are familiar to higher class families, the school system reproduces social inequalities (Bourdieu, Passeron, \& Nice, 1990). Not only does the school system unequally distribute grades and rewards among children depending on their parents' occupations, but it also makes people attribute school performance to internal factors, particularly their efforts or lack of efforts (Dompnier \& Pansu, 2010; Pansu, Dubois, \& Dompnier, 2008). In such a system, both low- and high-status individuals are led to believe that their success or failure is not due to their social background, but rather to differences in efforts and abilities (i.e., merit). In the present paper, we argue that meritocratic environments are particularly likely to make this internalization process occur. Indeed, the promotion of school merit among children is susceptible to affecting both the perception low and high SES students have of their ability to succeed within the system and their endorsement of system-justifying beliefs, two processes that - as detailed below - may contribute to increasing the SES achievement gap.

First, in meritocratic environments, performance is perceived as a relevant and accurate indicator of one's own ability (Trautwein, Lüdtke, Köller, \& Baumert, 2006). This point is of importance as school self-efficacy-that is, the extent to which individuals think they have the resources to succeed at school (Bandura, 1977) - is a consistent predictor of school success (Usher \& Pajares, 2006, 2008) and actually depends on social class (Gecas, 1989). Low social-class children are usually perceived as having lower abilities (Baron, Albright, \& Malloy, 1995) than their higher class counterparts. Wiederkehr, Darnon, Chazal, Guimond, and Martinot (2015) recently showed that low SES fifth-grade pupils performed more poorly than their high SES counterparts, in part because of a lower sense of school self-efficacy. Taken together, these results suggest that, in meritocratic environments, low and high SES students are likely to endorse self-perceptions that match the place they occupy in the hierarchy (i.e., low and high self-efficacy beliefs), which could further explain the SES achievement gap.

Second, meritocratic contexts push individuals to endorse beliefs that are susceptible to explaining and legitimating social inequalities. Such beliefs are expected to be particularly deleterious for low SES students. Indeed, outside of school, research has underscored the very role of meritocracy, especially in its descriptive form (i.e., believing the system is meritocratic), thereby making people accept the place they occupy within a system (O'Brien \& Major, 2009; Son Hing et al., 2011). According to system justification theory, meritocracy is one of the legitimizing myths through which a positive vision of the social system is maintained (Baron \& Banaji, 2009; Jost, Banaji, \& Nosek, 2004; Jost, Pelham, Sheldon, \& Sullivan, 2003), regardless of one's own social position (Jost \& Burgess, 2000; Ledgerwood, Mandisodza, Jost, \& Pohl, 2011; Sidanius \& Pratto, 1999). In meritocratic environments, members of advantaged groups are perceived as having worked harder than members of disadvantaged groups. Meritocracy promotes outgroup favouritism for members of low-status groups and in-group favouritism for members of high-status groups (Jost \& Hunyady, 2005; O'Brien \& Major, 2009). Preference for merit also predicts a denial of racial privileges among white 
participants (Knowles \& Lowery, 2012), pushes members of low-status groups to selfdescribe in a stereotyped way (McCoy \& Major, 2007), reduces the perception of discrimination (see also Major et al., 2002), and leads people to attribute the disadvantages of dominated groups to internal causes (Fraser \& Kick, 2000; Jost, 2001; see also Godfrey \& Wolf, 2016).

To sum up, priming school meritocracy should accentuate the SES achievement gap via two possible mechanisms. First, as developed above, SES affects school self-efficacy, which is positively related to performance. As a merit prime should favour the internalization process, it should strengthen the relationship between self-efficacy and performance. Second, priming merit should make both high and low SES children believe they deserve their position in the hierarchy and, thus, endorse system-justifying beliefs (i.e., belief in school meritocracy, BSM). As these beliefs are expected to be particularly self-debilitating for low-status groups' members, the negative link between BSM and performance should mainly be observed among low SES students. Thus, school selfefficacy and BSM will be tested as two potential mediators of the impact of merit prime on the SES achievement gap.

\section{Overview and hypotheses}

In the present research, low and high SES fifth-grade children were primed with a text that, depending on the condition, underscored either descriptive school meritocracy (merit prime condition) or an unrelated topic (control condition) before reporting their selfefficacy (in math and French) as well as their BSM. They then took school (math and French) tests. We expected the SES achievement gap to be strengthened in a merit prime context (H1). Self-efficacy and BSM will be tested as two processes expressed as two mediated moderations (Muller, Judd, \& Yzerbyt, 2005; Preacher, Rucher, \& Hayes, 2007) that could explain the impact of the merit prime on the SES achievement gap (cf. Figure 1). To validate mediated moderation 1 (self-efficacy), SES should predict school self-efficacy (H2), and the relationship between self-efficacy and performance should be higher in the merit prime condition than in the control group (H3). To validate mediated moderation 2 (BSM), the merit prime should increase BSM (H4), and the negative link between BSM and performance should be stronger among low SES students than among high SES students (H5).

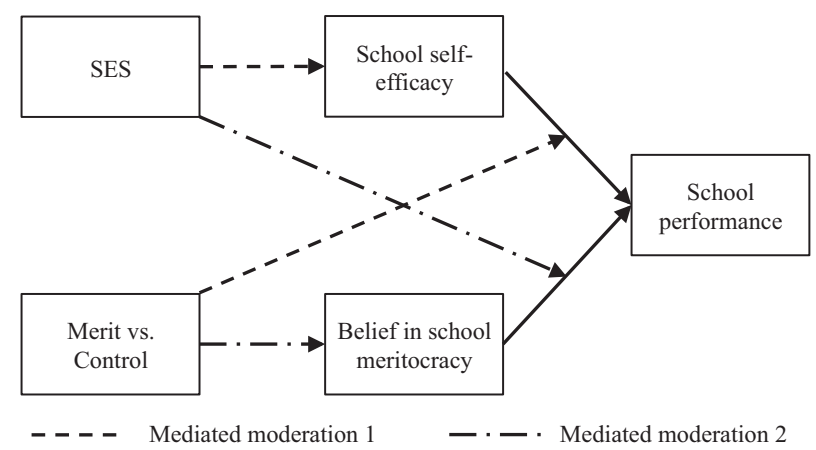

Figure I. Graphical representation of the two mediated moderations underlying the impact of merit prime on the SES achievement gap. 


\section{Method}

\section{Participants}

One hundred and forty-nine fifth-grade French children $\left(M_{\mathrm{age}}=10.13, S D=0.51\right.$; 80 girls, 66 boys, 3 not specified) voluntarily participated in this experiment during school hours. Approval from an ethical committee was obtained to conduct the research (ref $2013 \mathrm{CE} / 50$ ). An information letter was sent to parents a few weeks before the experiment was conducted. Only pupils for whom parental consent was obtained were included in the study. Assuming a small effect, our stopping rule for data collection was 35 participants per condition. However, participants whose parental profession was insufficiently described were not retained in the analyses $(N=25)$. The final sample comprised 124 participants $(65$ low SES and 59 high SES).

\section{Procedure}

Participants were given booklets containing all the material. Children were randomly assigned to one of the two conditions. In the 'merit prime' condition $(N=59 ; 33$ low SES, 26 high SES), the introductory text indicated that 'At school, everyone has the same chances to begin with, but only some students manage to succeed: those who have the ability and motivation. Indeed, to succeed in school, children have to deserve it. (...). Thus, if students fail, they can only blame themselves. To succeed in school, one just has to work well; it is only a matter of will'. ${ }^{1}$ In the control condition $(N=65$; 32 low SES, 33 high SES), a neutral text dealing with frogs' ability to anticipate disasters was presented. Children were asked to summarize the content in one sentence. They answered a BSM scale, the self-efficacy scales, and, then, solved the exercises. These last two measures were clustered in two domain-congruent sets-one in French and the other in mathematics - which were counterbalanced between participants. Participants were then debriefed. In particular, they were informed that school success did not only depend on merit and that some students might not succeed at a test for several reasons including being tired and being stressed, meaning that it was not 'their fault'.

\section{Measures}

School performance (tests)

Exercises were extracted from standardized national assessments for children. ${ }^{2}$ The French performance test included four exercises, combining spelling, punctuation, grammar, and reading comprehension. Scores could range between 0 and 21 $(M=15.39, S D=3.74)$. The mathematics material included six exercises, containing fractions, scientific vocabulary, operations, and geometry. Scores could range between 0 and $21(M=12.22, S D=4.62)$. Both French and mathematics scores were calculated blindly by the experimenter and based on a standardized evaluation matrix. Because we assumed that the same mechanism would concern both disciplines, performance scores were aggregated into a mean score of school performance $(\rho=.68, M=13.80$, $S D=3.63$ ).

\footnotetext{
${ }^{\prime}$ The full description of the material and data is available at: osf.io/mdvez

${ }^{2}$ For details, see http://cisad.pleiade.education.fr/evall
} 
Socioeconomic status

Children reported their mother's and father's occupations. Their categorization into a high SES or a low SES was based on the classification of the National Institute of Statistics and Economic Studies (see Smeding, Darnon, Souchal, Toczeck-Capelle, \& Butera, 2013). ${ }^{3}$

Belief in School Meritocracy (BSM)

Six items were used to measure BSM. Children reported the extent to which each sentence was true in school on a scale ranging from 1 ('totally disagree') to 6 ('completely agree'). As the initial Cronbach's alpha including all items was low $(\alpha=.42)$, only three items were kept in the final scale ('At school, where there is a will, there is a way', 'Everyone has the same chance to succeed in school', 'To succeed at school, one only has to work hard'; $\alpha=.58, M=5.48, S D=.07$ ).

\section{School self-efficacy}

A short version of the Joët, Usher, and Bressoux (2011) questionnaires was used to measure French and mathematics self-efficacy. Each scale contained 15 items $(\alpha=.73$, $M=3.40, S D=.40$ for French self-efficacy, e.g., 'I know the difference between singular and plural'; $\alpha=.75, M=3.37, S D=0.40$ for mathematics self-efficacy, e.g., 'I know how to calculate a subtraction mentally'). Children answered on a 4-point scale (from 1: 'not at all true' to 4: 'very true'). The two scales were correlated $(r=.44)$ and aggregated into a single score of school self-efficacy $(\alpha=.83, M=3.39, S D=0.34)$.

\section{Results}

Table 1 presents zero-order correlations among the variables. To test our hypotheses, four regression analyses were conducted on school performance (Models 1 and 4), self-efficacy (Model 2), and BSM (Model 3) and are presented in Table 2. Models 2, 3, and 4 correspond to the test of a second-stage moderated parallel multiple mediation model (Hayes, 2015).

Table I. Zero-order correlations among variables

\begin{tabular}{lcccccr}
\hline & 1 & 2 & 3 & 4 & 5 & 6 \\
\hline I. Belief in School Meritocracy (BSM) & & & & & & \\
2. French self-efficacy & .15 & & & & & \\
3. Mathematic self-efficacy & .11 & $.44^{* * *}$ & & & & \\
4. Performance (French) & -.10 & $.33^{* * *}$ & $.20^{*}$ & & & \\
5. Performance (Maths) & -.15 & $.32^{* * *}$ & $.35^{* * *}$ & $.50^{* * *}$ & & \\
6. Merit prime & $.21^{*}$ & .01 & .03 & -.16 & -.00 & \\
7. Socioeconomic status & -.12 & .11 & $.21^{*}$ & $.25^{* *}$ & $.19^{*}$ & -.07 \\
\hline
\end{tabular}

Note. Merit prime is coded - I for control condition, + I for merit prime condition. Socioeconomic status is coded - I for low SES, + I for high SES.

$* p<.05 ; * * p<.01 ; * * p<.001$.

\footnotetext{
${ }^{3}$ The National Institute of Statistics and Economic Studies is a sort of census bureau (see http://www.insee.fr/en). In case of a discrepancy between the father's and the mother's SES, the highest parental SES was retained. If an occupation was reported for only one of the parents, this single occupation was used to code students' SES.
} 


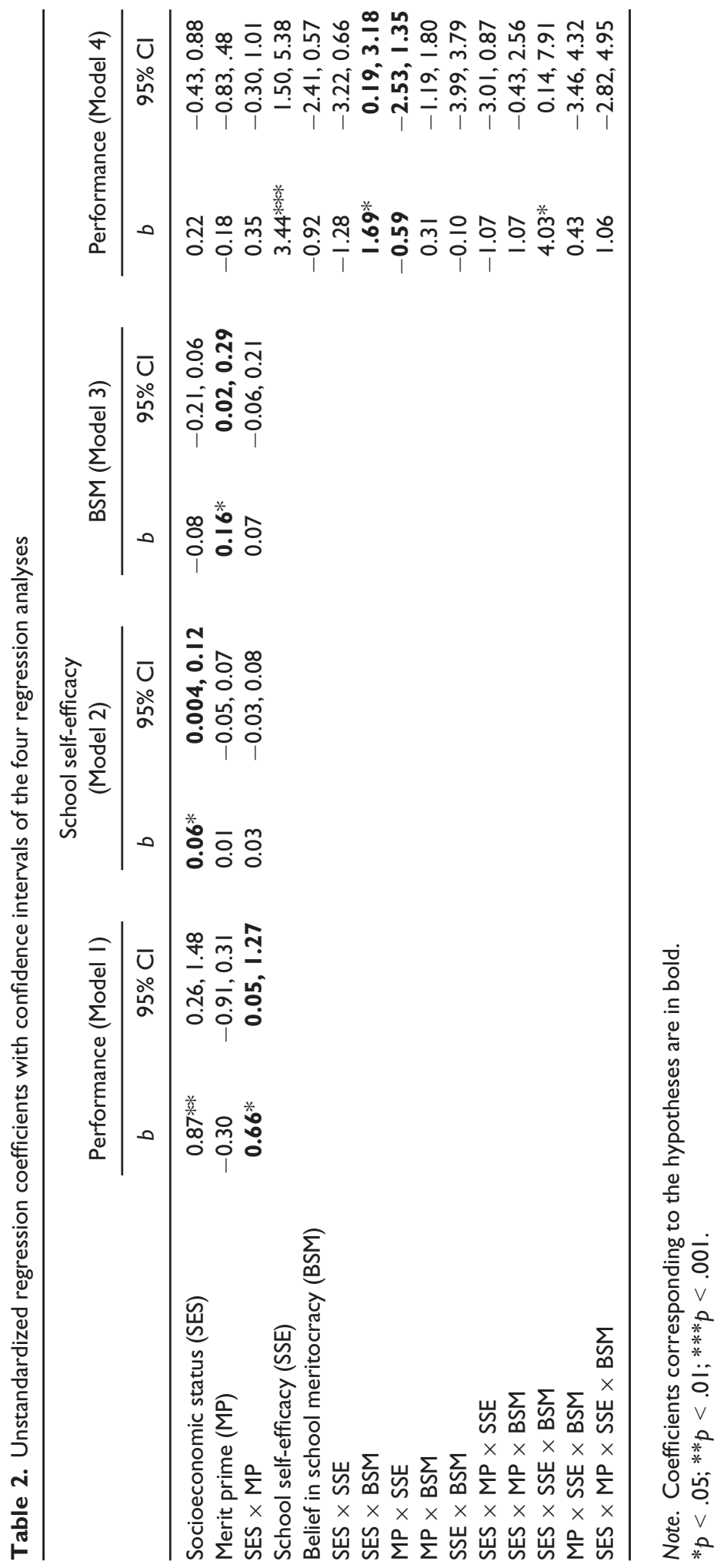




\section{Does merit prime increase the SES achievement gap?}

A first regression analysis was conducted with SES (coded -1 for low SES,+1 for high SES students), merit prime (coded -1 for the control condition, +1 for the merit condition), and their interaction product as predictors and school performance as a dependent variable (Model 1). The effect of SES was significant, $b=0.87$, $t(120)=2.83, p=.005, \eta_{p}^{2}=.06$. High SES students $(M=14.85 ; S D=3.01)$ performed better than low SES students $(M=13.14 ; S D=3.81)$. The effect of merit prime was not significant, $t(120)>-1$, but the interaction was $b=0.66$, $t(120)=2.15, p=.03, \eta_{p}^{2}=.04$ (cf. Figure 2). Supporting H1, whereas high SES students did not differ as a function of the condition, $t(120)<1$, low SES students obtained a lower performance score in the merit prime condition than in the control condition, $b=-0.96, t(120)=-2.27, p=.03$.

\section{Why does merit prime increase the SES achievement gap?}

\section{School self-efficacy}

Regressing school self-efficacy on SES, merit prime, and their interaction product (Model 2) revealed a significant main effect of SES, $b=0.06, t(120)=2.12, p=.04, \eta_{p}^{2}=.04$. In line with $\mathrm{H} 2$, high SES students $(M=3.44 ; S D=0.28)$ had a higher school self-efficacy than low SES students $(M=3.31 ; S D=0.37)$. Neither the effect of merit prime nor the interaction between SES and merit prime reached significance, $t$ s $(120)<1$.

\section{Belief in school meritocracy}

The same regression model was also used to predict BSM (Model 3). The effect of the condition was significant, $b=0.16, t(120)=2.32, p=.02, \eta_{p}^{2}=.04$. As expected by $\mathrm{H} 4$, BSM was higher in the merit prime $(M=5.66 ; S D=0.51)$ than in the control condition $(M=5.34 ; S D=0.92)$. No other effect reached significance, $-1.12<t<1.10$.

\section{School performance}

A last model was regressed on school performance with SES, merit prime, school selfefficacy, BSM (both mean-centred), and all interaction products as predictors (Model 4).

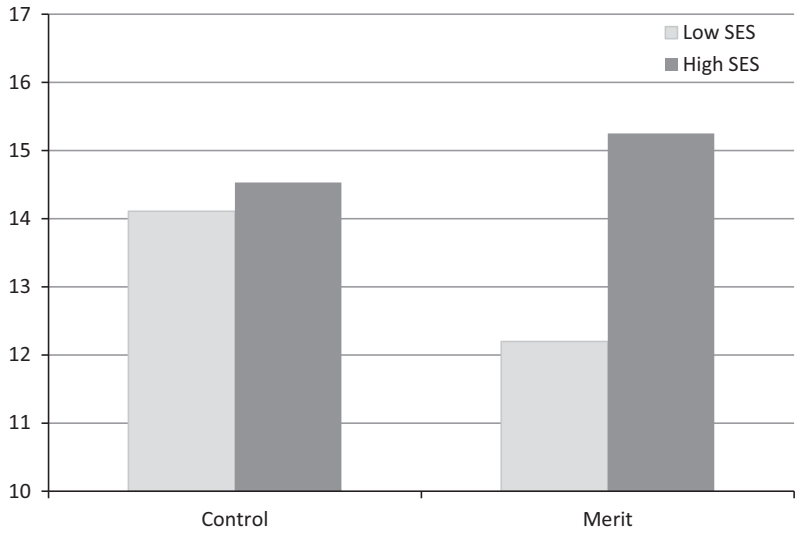

Figure 2. Mean school performance as a function of SES and merit prime. 


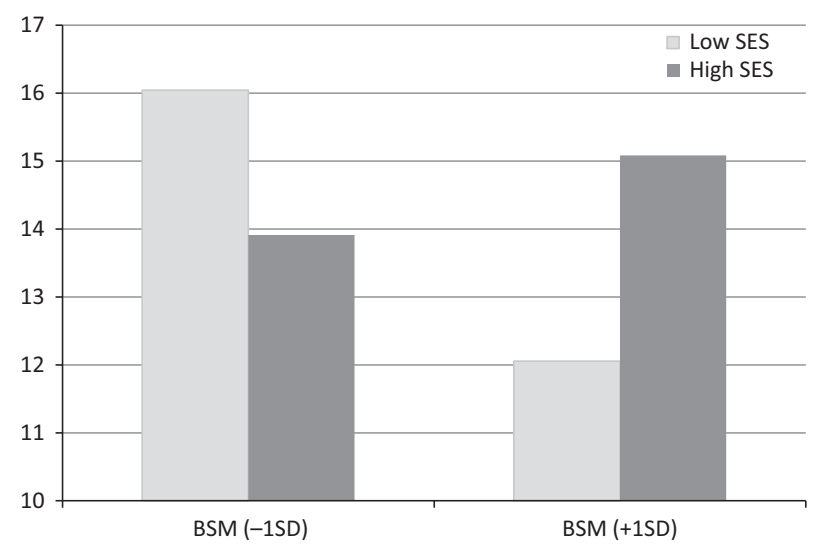

Figure 3. Mean school performance as a function of belief in school meritocracy (BSM) and SES.

School self-efficacy was related to school performance, $b=3.44, t(108)=3.52$, $p=.0006, \eta_{p}^{2}=.10$. More importantly, as expected by $\mathrm{H} 5$, the interaction between SES and BSM reached significance (cf. Figure 3), $b=1.69, t(108)=2.24, p=.03$, $\eta_{p}^{2}=.04:$ BSM was significantly and negatively related to performance among low SES students, $b=-2.61, t(108)=-2.93, p=.004$, but not significant among high SES students, $b=0.76, t(108)<1$.

In addition, this last interaction was moderated by school self-efficacy, $b=4.03$, $t(108)=2.05, p=.04, \eta_{p}^{2}=.04:$ the higher the students' school self-efficacy, the stronger the interaction between SES and BSM. In other words, the relationship between BSM and performance was more negative among low SES students with a high level of selfefficacy $(+1 S D), b=-3.99, t(108)=-2.85, p=.005$, than among low SES students with a low level of self-efficacy $(-1 S D), b=-1.22, t(108)=-2.08, p=.04$. It was not significant among high SES students with a high $(+1 S D)$ or a low level $(-1 S D)$ of selfefficacy, respectively, $b=2.08, t(108)=1.55, p=.12$, and $b=-0.55, t(108)>-1$.

No other effect reached significance, $-1.32<t \mathrm{~s}<1.42, p \mathrm{~s} \geq .16$. This lack of additional results enabled several conclusions. First, the lack of significance of interaction between school self-efficacy and merit prime indicated that $\mathrm{H} 3$ was not supported, $b=-0.59, t(108)>-1$. Second, when controlled by the other terms included in the model, the interaction between SES and merit prime previously observed (H1; cf. Model 1) was strongly reduced and did not predict school performance anymore, $b=0.35, t$ $(108)=1.07, p=.29$.

In sum, these findings revealed that the increase in the SES performance gap produced by the merit prime was explained by mediated moderation 2 (BSM) but not by mediated moderation 1 (school self-efficacy): Both $\mathrm{H} 4$ and $\mathrm{H} 5$ were supported by the data, whereas only H2 (but not H3) was confirmed. ${ }^{4}$

\footnotetext{
${ }^{4}$ As explained in the Method section, math and French performances and self-efficacy beliefs were aggregated into two single scores of school performance and school self-efficacy. This aggregation relied on the assumption that the same process would apply for both domains. To test this assumption, a last set of analyses tested whether results obtained varied across the two disciplines (French versus math). To this end, within-subject variables contrasting the two fields were created for self-efficacy and performance and used as dependent variables (cf. Judd, McClelland, \& Ryan, 2009). The results obtained indicated that the field did not significantly moderate the effects involved in the test of the five hypotheses, all ps $>.36$, supporting the assumption that the conclusions raised from the tests of the two mediated moderations can be considered similar in both domains.
} 


\section{Discussion}

The ideology of merit is a powerful instrument for system justification (Jost et al., 2004; Sidanius \& Pratto, 1999; Son Hing et al., 2011). The present paper examined whether in the school context, priming merit contributes to accentuating the SES achievement gap. This question has important practical implications as merit is often promoted in the school context and low SES students have repeatedly been shown to have a poorer school achievement than their high SES counterparts. We argued that meritocracy is likely to favour an internalization process, through which low and high social-class children attribute to themselves individual characteristics (i.e., low versus high self-efficacy) and endorse system-justifying beliefs (BSM) - two processes that may further explain their low or high performance. The present results support that priming merit has produced an increase in the achievement gap. As far as the two mediated moderation processes are concerned, the results indicated that BSM, more than self-efficacy, seems to be the key mechanism explaining this effect. Indeed, the merit prime increased BSM endorsement (H4). Moreover, the link between BSM and performance is stronger among low SES than among high SES students (H5). Again, this last result has important practical implications as it indicates that BSM contributes to accentuating the SES achievement gap and, as such, can be considered a 'self-debilitating' belief (Sidanius \& Pratto, 1999). The irony is that low SES students have recently been shown to be precisely the ones who endorsed the most BSM when their place within the system is challenged (McCoy, Wellman, Cosley, Saslow, \& Epel, 2013; Wiederkehr, Bonnot, et al., 2015). Although school meritocracy is often presented as a way to fight social inequalities, the present results suggest that endorsing such beliefs may in fact accentuate social inequalities.

The results also suggest that the moderation of the link between BSM and performance by SES (i.e., negative for low SES, non-significant for high SES) increases with self-efficacy. Although unexpected, this result is coherent with some findings showing that low SES students who seem to suffer the most from their status are, surprisingly, those who achieve quite well in the system (Jury, Smeding, Court, \& Darnon, 2015; Jury, Smeding \& Darnon, 2015). A potential explanation is that students who have both low SES and low self-efficacy might disengage from academics. Future research should examine this hypothesis.

The present findings echo some results obtained in the stereotype threat literature on adults (Croizet \& Claire, 1998; Spencer \& Castano, 2007) and children (Désert, Préaux, \& Jund, 2009), showing that the SES achievement gap is particularly likely to occur when negative stereotypes about low SES students are activated. Although our merit prime did not mention SES, in future research, the implicit activation of the SES stereotype could be tested as another potential mediator of the SES by merit prime interaction on school performance. The results would also benefit from being replicated with a control for initial French and math abilities. Finally, although mainly focused on effort, the present induction of merit underscored the role of both efforts and ability in explaining school success, which may explain the quite low effect size. Effort is more controllable than ability. Consequently, the internalization process is particularly likely to occur under the salience of effort-based merit. However, future research should disentangle the respective role of effort versus ability salience in increasing the SES school achievement gap.

Merit is a widespread ideology in Western societies (Kraus \& Tan, 2015) and is particularly present at school. The present findings showed that merit prime leads low and high SES children to endorse system-justifying beliefs (BSM) that in turn contribute to reproducing and accentuating the SES achievement gap. In terms of practice, there are a 
few reasons not to promote effort and hard work at school. Indeed, effort is a sine qua non condition for learning (Dweck, 1999). However, we believe effort should not be described and presented as the only factor that determines school success and failure not to legitimate, perpetuate, and accentuate the achievement gap.

\section{Acknowledgement}

This research was supported by the Conseil Regional Auvergne.

\section{References}

Aikens, N. L., \& Barbarin, O. (2008). Socioeconomic differences in reading trajectories: The contribution of family, neighborhood, and school contexts. Journal of Educational Psychology, 100, 235-251. https://doi.org/10.1037/0022-0663.100.2.235

Arnold, D. H., \& Doctoroff, G. L. (2003). The early education of socioeconomically disadvantaged children. Annual Review of Psychology, 54, 517-545. https://doi.org/10.1146/annurev.psych. 54.111301.145442

Bandura, A. (1977). Self-efficacy: Toward a unifying theory of behavioral change. Psychological Review, 84, 191-215.

Baron, R. M., Albright, L., \& Malloy, T. E. (1995). Effects of behavioral and social class information on social judgment. Personality and Social Psychology Bulletin, 21, 308-315. https://doi.org/10. $1177 / 0146167295214001$

Baron, A., \& Banaji, M. (2009). Evidence of system justification in young children. Social and Personality Psychology Compass, 3, 918-926. https://doi.org/10.1111/j.1751-9004.2009.00 214.x

Bourdieu, P., Passeron, J. C., \& Nice, R. (1990). Reproduction in education, society and culture. London, UK: SAGE.

Bradley, R. H., \& Corwyn, R. F. (2002). Socioeconomic status and child development. Annual Review of Psychology, 53, 371-399. https://doi.org/10.1146/annurev.psych.53.100901.135 233

Croizet, J. C., \& Claire, T. (1998). Extending the concept of stereotype and threat to social class: The intellectual underperformance of students from low socioeconomic backgrounds. Personality and Social Psychology Bulletin, 24, 588-594. https://doi.org/10.1177/0146167298246003

Désert, M., Préaux, M., \& Jund, R. (2009). So young and already victims of stereotype threat: Socioeconomic status and performance of 6 to 9 years old children on Raven's progressive matrices. European Journal of Psychology of Education, 24, 207-218. https://doi.org/10.1007/BF031 73012

Dompnier, B., \& Pansu, P. (2010). La valeur sociale des explications causales en contexte éducatif: Autoprésentation des élèves et représentation des enseignants [Social value of causal explanations in educational settings: Pupils' self-presentation and teachers' representations]. Swiss Journal of Psychology, 69, 39-51. https://doi.org/10.1024/1421-0185.a000005

Dweck, C. S. (1999). Self-theories: Their role in motivation, personality, and development. New York, NY: Psychology Press.

Fraser, J., \& Kick, E. (2000). The interpretive repertoires of whites on race- targeted policies: Claims making of reverse discrimination. Sociological Perspectives, 43, 13-28. https://doi.org/10. $2307 / 1389780$

Galindo, C., \& Sonnenschein, S. (2015). Decreasing the SES math achievement gap: Initial math proficiency and home learning environments. Contemporary Educational Psychology, 43, 25-38. https://doi.org/10.1016/j.cedpsych.2015.08.003

Gecas, V. (1989). The social psychology of self-efficacy. Annual Review of Sociology, 15, 291-316. https://doi.org/10.1146/annurev.so.15.080189.001451 
Godfrey, E. B., \& Wolf, S. (2016). Developing critical consciousness or justifying the system? A qualitative analysis of attributions for poverty and wealth among low-income racial/ethnic minority and immigrant women. Cultural Diversity and Ethnic Minority Psychology, 22, 93-103. https://doi.org/10.1037/cdp0000048

Goudeau, S., Autin, F., \& Croizet, J. C. (2017). Studying social class in psychology: Economic, symbolic and cultural approaches. International Review of Social Psychology, 30, 1-19. https://doi.org/10.5334/irsp.52

Hayes, A. F. (2015). An index and test of linear moderated mediation. Multivariate Behavioral Research, 50, 1-22. https://doi.org/10.1080/00273171.2014.962683

Joët, G., Usher, E. L., \& Bressoux, P. (2011). Sources of self-efficacy: An investigation of elementary school students in France. Journal of Educational Psychology, 103, 649-663. https://doi.org/ $10.1037 / \mathrm{a} 0024048$

Jordan, N. C., \& Levine, S. C. (2009). Socioeconomic variation, number competence, and mathematics learning difficulties in young children. Developmental Disabilities Research Reviews, 15, 60-68. https://doi.org/10.1002/ddrr.46

Jost, J. T. (2001). Outgroup favoritism and the theory of system justification: An experimental paradigm for investigating the effects of socio-economic success on stereotype content. In G. Moskowitz (Ed.), Cognitive social psychology: The Princeton symposium on the legacy and future of social cognition (pp. 89-102). Mahwah, NJ: Erlbaum.

Jost, J. T., Banaji, M. R., \& Nosek, B. A. (2004). A decade of system justification theory: Accumulated evidence of conscious and unconscious bolstering of the status quo. Political Psychology, 25, 881-920. https://doi.org/10.1111/j.1467-9221.2004.00402.x

Jost, J. T., \& Burgess, D. (2000). Attitudinal ambivalence and the conflict between group and system justification motives in low status groups. Personality and Social Psychology Bulletin, 26, 293-305. https://doi.org/10.1177/0146167200265003

Jost, J. T., \& Hunyady, O. (2002). The psychology of system justification and the palliative function of ideology. European Review of Social Psychology, 13, 111-153. https://doi.org/10.1080/10463 280240000046

Jost, J. T., \& Hunyady, O. (2005). Antecedents and consequences of system-justifying ideologies. Current Directions in Psychological Science, 14, 260-265. https://doi.org/10.1111/j.09637214.2005.00377.x

Jost, J. T., Pelham, B. W., Sheldon, O., \& Sullivan, B. N. (2003). Social inequality and the reduction of ideological dissonance on behalf of the system: Evidence of enhanced system justification among the disadvantaged. European Journal of Social Psychology, 33, 13-36. https://doi.org/10. $1002 /$ ejsp. 127

Judd, C. M., McClelland, G., \& Ryan, C. S. (2009). Data analysis: A model comparison approach. New York, NY: Routledge.

Jury, M., Smeding, A., Court, M., \& Darnon, C. (2015). When first-generation students succeed at university: On the link between social class, academic performance, and performance-avoidance goals. Contemporary Educational Psychology, 41, 25-36. https://doi.org/10.1016/j.cedpsych. 2014.11.001

Jury, M., Smeding, A., \& Darnon, C. (2015). First-generation students' underperformance at university: The impact of the function of selection. Frontiers in Pyschology, 6. https://doi.org/ 10.3389/fpsyg.2015.00710

Knowles, E. D., \& Lowery, B. S. (2012). Meritocracy, self-concerns, and Whites' denial of racial inequity. Self and Identity, 11, 202-222. https://doi.org/10.1080/15298868.2010.542015

Kraus, M. W., \& Tan, J. J. X. (2015). Americans overestimate social class mobility. Journal of Experimental Social Psychology, 58, 101-111. https://doi.org/10.1016/j.jesp.2015.01.005

Ledgerwood, A., Mandisodza, A. N., Jost, J., \& Pohl, M. J. (2011). Working for the system: Motivated defense of meritocratic beliefs. Social Cognition, 29, 322-340. https://doi.org/10.1521/soco. 2011.29.3.322 
Major, B., Gramzow, R. H., McCoy, S. K., Levin, S., Schmader, T., \& Sidanius, J. (2002). Perceiving personal discrimination: The role of group status and legitimizing ideology. Journal of Personality and Social Psychology, 82, 269-282. https://doi.org/10.1037/0022-3514.82.3.269

McCoy, S. K., \& Major, B. (2007). Priming meritocracy and the psychological justification of inequality. Journal of Experimental Social Psychology, 43, 341-351. https://doi.org/10.1016/ j.jesp.2006.04.009

McCoy, S. K., Wellman, J. D., Cosley, B., Saslow, L., \& Epel, E. (2013). Is the belief in meritocracy palliative for members of low status groups? Evidence for a benefit for self-esteem and physical health via perceived control. European Journal of Social Psychology, 43, 307-318. https://doi. org/10.1002/ejsp.1959

Mijs, J. J. B. (2016). The unfulfillable promise of meritocracy: Three lessons and their implications for justice in education. Social Justice Research, 29, 14-34. https://doi.org/10.1007/s11211-0140228-0

Muller, D., Judd, C. M., \& Yzerbyt, V. Y. (2005). When moderation is mediated and mediation is moderated. Journal of Personality and Social Psychology, 89, 852-863. https://doi.org/10. 1037/0022-3514.89.6.852

O'Brien, L., \& Major, B. (2009). Group status and feelings of personal entitlement: The roles of social comparison and system-justifying beliefs. In J. T. Jost, A. C. Kay \& H. Thorisdottir (Eds.), Social and psychological bases of ideology and system justification (pp. 427-443). New York, NY: Oxford University Press.

Pansu, P., Dubois, N., \& Dompnier, B. (2008). Internality-norm theory in educational contexts. European Journal of Psychology of Education, 23, 385-397. https://doi.org/10.1007/BF03 172748

Preacher, K. J., Rucher, D. D., \& Hayes, A. F. (2007). Addressing moderated mediation hypotheses: Theory, methods, and prescriptions. Multivariate Behavioral Research, 42, 185-227. https:// doi.org/10.1080/00273170701341316

Sidanius, J., \& Pratto, F. (1999). Social dominance: An intergroup theory of social Hierarchy and oppression. New York, NY: Cambridge University Press.

Sirin, S. R. (2005). Socioeconomic status and academic achievement: A meta-analytic review of research. Review of Educational Research, 75, 417-453. https://doi.org/10.3102/00346543 075003417

Smeding, A., Darnon, C., Souchal, C., Toczeck-Capelle, M. C., \& Butera, F. (2013). Reducing the socio-economic status achievement gap at university by promoting mastery-oriented assessment. PLoS ONE, 8, e71678. https://doi.org/10.1371/journal.pone.0071678

Son Hing, L. S., Bobocel, D. R., Zanna, M. P., Garcia, D. M., Gee, S. S., \& Orazietti, K. (2011). The merit of meritocracy. Journal of Personality and Social Psychology, 101, 433-450. https://doi.org/ $10.1037 / \mathrm{a} 0024618$

Spencer, B., \& Castano, E. (2007). Social class is dead. Long live social class! Stereotype threat among low socioeconomic status individuals. Social Justice Research, 20, 418-432. https://doi.org/10. 1007/s11211-007-0047-7

Trautwein, U., Lüdtke, O., Köller, O., \& Baumert, J. (2006). Self-esteem, academic self-concept, and achievement: How the learning environment moderates the dynamics of self-concept. Journal of Personality and Social Psychology, 90, 334-349. https://doi.org/10.1037/0022-3514.90.2. 334

Usher, E. L., \& Pajares, F. (2006). Inviting confidence in school: Invitations as a critical source of the academic self-efficacy beliefs of entering middle school students. Journal of Invitational Theory and Practice, 12, 7-16.

Usher, E. L., \& Pajares, F. (2008). Sources of self-efficacy in school: Critical review of the literature and future directions. Review of Educational Research, 78, 751-796. https://doi.org/10.3102/ 0034654308321456

White, K. (1982). The relation between socioeconomic status and academic achievement. Psychological Bulletin, 91, 461-481. https://doi.org/10.3102/0034654308321456 
Wiederkehr, V., Bonnot, V., Krauth-Gruber, S., \& Darnon, C. (2015). Belief in school meritocracy as a system-justifying tool for low status students. Frontiers in Psychology, 6, 1053. https://doi.org/ $10.3389 /$ fpsyg.2015.01053

Wiederkehr, V., Darnon, C., Chazal, S., Guimond, S., \& Martinot, D. (2015). From social class to selfefficacy: Internalization of low social status pupils' school performance. Social Psychology of Education: An International Journal, 18, 769-784. https://doi.org/10.1007/s11218-015-9308-8

Received 6 March 20I 7; revised version received 24 July 2017 